Article

\title{
An Epidemiological Study Report on the Antioxidant and Phenolic Content of Selected Mediterranean Functional Foods, Their Consumption Association with the Body Mass Index, and Consumers Purchasing Behavior in a Sample of Healthy Greek Adults
}

\author{
Aikaterini Kandyliari ${ }^{1}$, Ioannis-Nektarios Elmaliklis ${ }^{1}$, Olga Kontopoulou ${ }^{1}$, Marianna Tsafkopoulou ${ }^{1}$, \\ Georgios Komninos ${ }^{1}$, Christina Ntzatha ${ }^{1}$, Andreas Petsas ${ }^{2}$, Haralabos C. Karantonis ${ }^{2}$ and \\ Antonios E. Koutelidakis 1 **iD
}

Citation: Kandyliari, A.; Elmaliklis, I.-N.; Kontopoulou, O.; Tsafkopoulou, M.; Komninos, G.; Ntzatha, C.; Petsas, A.; Karantonis, H.C.; Koutelidakis,

A.E. An Epidemiological Study Report on the Antioxidant and Phenolic Content of Selected Mediterranean Functional Foods, Their Consumption Association with the Body Mass Index, and Consumers Purchasing Behavior in a Sample of Healthy Greek Adults. Appl. Sci. 2021, 11, 7818. https://doi.org/10.3390/ app11177818

Academic Editors:

Wojciech Kolanowski and

Monica Gallo

Received: 18 July 2021

Accepted: 24 August 2021

Published: 25 August 2021

Publisher's Note: MDPI stays neutral with regard to jurisdictional claims in published maps and institutional affiliations.

Copyright: (c) 2021 by the authors Licensee MDPI, Basel, Switzerland. This article is an open access article distributed under the terms and conditions of the Creative Commons Attribution (CC BY) license (https:// creativecommons.org/licenses/by/ $4.0 /)$.
1 Laboratory of Nutrition and Public Health, Unit of Human Nutrition, Department of Food Science and Nutrition, University of the Aegean, 81400 Myrina, Greece; kandyliari@aegean.gr (A.K.); ioannis.elmaliklis@gmail.com (I.-N.E.); fns12037@fns.aegean.gr (O.K.); fns11102@fns.aegean.gr (M.T.); fns09043@fns.aegean.gr (G.K.); fns12076@fns.aegean.gr (C.N.)

2 Laboratory of Food Chemistry, Biochemistry and Technology, Department of Food Science and Nutrition, University of the Aegean, 81400 Myrina, Greece; apetsas@aegean.gr (A.P.); chkarantonis@aegean.gr (H.C.K.)

* Correspondence: akoutel@aegean.gr; Tel.: +30-225-408-3123 or +30-693-707-1806

\begin{abstract}
Functional food consumption is shown to have a positive effect on anthropometric parameters and human health promotion. In addition, consumers seem to be more interested in food choices, that may have a positive effect on their health. The current study aimed to identify the antioxidant and phenolic content of naturally functional foods from the Mediterranean diet and to investigate consumer behavior towards their consumption in terms of their weight control, as well as their purchasing behavior and knowledge of functional foods. For this purpose, blueberries, cranberries, pomegranate, grapefruit, red peppers, almonds and mountain tea were analyzed for their phenolic content and antioxidant capacity, using the Folin-Ciocalteau and Ferric Reducing Antioxidant Power assays, respectively. Furthermore, nine hundred forty-nine healthy Greek adults participated in an epidemiological study, by completing a validated food frequency questionnaire, for the consumption of the above investigated functional foods. Five hundred and fifty participants also completed an online questionnaire investigating factors that consumers evaluate when purchasing functional foods. Study results showed that the analyzed functional foods were high in antioxidants and phenolic compounds, especially the mountain tea. The increased consumption of cranberries, pomegranate, grapefruit, red peppers and mountain tea was significantly correlated with a decreased Body Mass Index, suggesting a possible positive role, in weight control. Participants seemed to be aware of the beneficial role of these specific investigated Mediterranean functional foods to human health. They evaluated the price, taste and nutritional value, as critical factors to buy these food products. A combination of factors seems to lead them to purchase and consume these functional foods. Future epidemiological and clinical studies should be conducted in order to further evaluate consumer preferences and bioactivity mechanisms related to Mediterranean functional food consumption.
\end{abstract}

Keywords: berries; pomegranates; grapefruits; red peppers; almonds; mountain tea; antioxidant content; Mediterranean functional foods; body mass index; consumer's preferences

\section{Introduction}

The term "functional foods" first appeared in Japan in 1984, when the country's scientific community defined them as foods that meet nutritional needs, provide satisfaction and have a positive effect on the human body [1]. Nowadays, researchers use 
the term "functional" for foods that contain bioactive compounds, such as antioxidants, fiber, phytosterols, probiotics and prebiotics and their consumption is associated with possible health promotion [2]. Foods with functional properties are used as an important component for healthy diets and for the prevention of several diseases [3-6]. Scientific data indicate that functional foods may contribute towards the prevention of the prevalence of chronic diseases including metabolic syndrome and obesity $[7,8]$. Given the fact that obesity remains a global burden [9], a balanced diet and functional foods could contribute complementarily, to reduced comorbidities [7].

The consumption of several types of functional foods, such as green tea, green coffee, red peppers, blueberries, goji berries, cranberries, nuts, kefir, etc. have been investigated as potential parameters for weight control [10]. Their content of functional ingredients, especially antioxidant compounds, polyphenols, such as quercetin, tannins, anthocyanins and other flavonoids, vitamins, minerals, carotenoids and probiotics, has been studied for its association with the mechanisms of thermogenesis, lipolysis and satiety [11]. In the Mediterranean diet, the consumption of natural functional foods, such as specific fruits, vegetables, legumes, wild greens, herbs, nuts, olives, and olive oil, rich in a plethora of bioactive compounds, has been associated with the prevention of chronic diseases and overall health promotion $[5,6,11]$. However, factors, such as the growing location, cultivation practices and genetic factors influence the antioxidant activity of these foods [12,13]. Therefore, differences may exist among vegetables and fruits originating from different countries.

In the last decades, the evident health benefits associated with the consumption of functional foods, have become more popular among consumers [14]. Consequently, consumer needs for nutritious food choices have led to a growth in the global functional food market [15]. Therefore, understanding the preferences and reasons that lead consumers to their food purchasing choices, remains crucial for the sector [16]. It will also help health professionals and researchers to raise awareness on healthy food choices in a more suitable way, in order for nutritional policies to be established [17]. However, implemented studies have found mixed and contradictory factors affecting consumer behavior, such as price of functional foods [18], health benefits [19] and even different socioeconomic characteristics and socio-cultural factors [15]. Country-specific studies will contribute towards shedding light on consumer perceptions and better understand their needs.

In Greece, specific studies have shown that functional food consumption is not widespread, although consumers are aware of the potential association of functional foods with health promotion $[20,21]$. Therefore, a better understanding of consumer food choices, while also determining the nutritional content of functional foods and strengthening the hypothesis of their beneficial role to health, could have a significant impact on the utilization and acceptance of functional foods.

The objective of the present study was to identify the total phenolic content and the total antioxidant activity of blueberries, cranberries, pomegranates, grapefruits, red peppers, almonds and mountain tea, natural functional foods cultivated in Southern Greece and often consumed as part of the Mediterranean diet. In parallel, this is the first epidemiological study to our knowledge that was conducted in Greece and provides an insight into the association between consumption frequency of foods studied for their antioxidant activity and the Body Mass Index (BMI) of the consumers, as well as the consumers' preferences over these products and functional foods in general.

\section{Materials and Methods}

In the context of the present study, an in vitro study was carried out to evaluate the antioxidant capacity and total phenolic content of various selected Mediterranean functional foods cultivated in Southern Greece, that have been associated with possible impacts on weight control. In addition, an epidemiological study was performed to investigate their consumption and the consumer preferences in a sample of healthy adults 
from various regions of Greece without chronic diseases, such as cardiovascular diseases, diabetes, and cancer.

\subsection{In Vitro Study of Antioxidant Content}

\subsubsection{Preparation of Sample Extracts}

Blueberries $(n=15)$, cranberries $(n=15)$, pomegranates $(n=5)$, grapefruits $(n=5)$, red peppers $(n=5)$ and almonds $(n=15)$ were purchase from local market in Lemnos Island, Greece. The origin of the selected fruits and vegetables was from Southern Greece. At least five samples were used from each food product and pooled together. Then they were homogenized using a kitchen blender. Two grams of each food were added in a conical flask with $50 \mathrm{~mL}$ of $50 \%$ aqueous ethanol. The flasks were placed in an ultrasonic water bath (ELMASONIC P, ELMA, Singen (Hohentwiel), Germany) for $1 \mathrm{~h}$. Filtration of the extract was followed by filter paper. For the preparation of mountain tea extract, $1 \mathrm{~g}$ of the plant was immersed in $50 \mathrm{~mL}$ of warm water for $5 \mathrm{~min}$, following by filtration of the extract.

All extracts were collected in plastic tubes and stored at $-80^{\circ} \mathrm{C}$, until further analysis.

\subsubsection{Determination of Antioxidant Content}

Total Antioxidant Activity by Ferric Reducing Antioxidant Power Assay

The total antioxidant activity of samples (food extracts) was determined by the ferric reducing antioxidant power (FRAP) assay $[18,22,23]$. This method is based on the conversion of the TPTZ- $\mathrm{Fe}^{+3}$ complex to TPTZ- $\mathrm{Fe}^{2+}$ and determining its amplitude by measuring the absorbance at $595 \mathrm{~nm}$ with a spectrophotometer (SPARK, TECAN, Männedorf, Switzerland). The larger absorption difference is related to the greater capacity of the antioxidant to convert TPTZ- $-\mathrm{Fe}^{+3}$ complex to TPTZ- $\mathrm{Fe}^{2+}$. Antioxidant activity was quantified using a $\mathrm{FeSO}_{4}$ curve and the results of FRAP assay are expressed in mmol of $\mathrm{Fe}^{2+}$ equivalents per gram of food sample. Analysis was performed in triplicate. All reagents were purchased by Sigma-Aldrich (Steinheim, Germany).

\section{Total Phenolic Content by Folin-Ciocalteau Assay}

The total phenolic content of the samples was determined by the Folin-Ciocalteau method. This method is based on the reduction of the Folin-Ciocalteau reagent in an alkaline environment and measurement of the absorbance at $765 \mathrm{~nm}$ with a spectrophotometer (SPARK, TECAN, Switzerland) [24,25]. The total phenolics were quantified using a standard gallic acid curve and the results were expressed in milligram gallic acid equivalents per gram of food sample. Analysis was performed in triplicate. All reagents were purchased by Sigma-Aldrich.

\subsection{Epidemiological Study}

\subsubsection{Participants}

Out of 1073 initially distributed questionnaires, 949 were validly completed by the participants. Participants who were selected were healthy adults aged 18-65 years old, from different regions of Greece and completed the online questionnaire with a duration from January 2017 to October 2019. The recruitment of the participants was carried out via social media and online announcements, in a random and representative way (according to the different areas of northern, central, and southern Greece). The inclusion-selection criteria also required volunteers to be healthy adults who had never suffered from chronic diseases, inflammations, or infections, such as cardiovascular diseases, diabetes mellitus, cancer and psychological diseases. These criteria were chosen aiming to better investigate the potential role of functional foods to healthy adults and their opinion about functional food consumption, as the presence of other chronic diseases such as cancer, cardiovascular diseases and diabetes may change the dietary patterns of the participants and may be correlated with weight management programs adoption. Exclusion criteria encompassed 
individuals over the age of 65 and under the age of 18 years, due to the different nutritional needs of younger people and the elderly.

\subsubsection{Study Design}

The study was a retrospective, observational, epidemiological study. The study protocol was conducted in accordance with the Declaration of Helsinki. The participants signed a consent form and were informed about the prime target of the study, the confidentiality of the data, the voluntary nature of the study and the acceptance of their participation. Then, they completed an online questionnaire to assess their dietary patterns and functional food consumption frequency, where they were asked to recall their nutritional habits for the past year. For the determination of their Body Mass Index (BMI), self-reported weight and height were provided. Five hundred and fifty participants out of the nine hundred and forty-nine initially registered to the study also completed another questionnaire to investigate their awareness of dietary functional foods and factors affecting their attitudes and intentions, towards functional food purchasing. However, it should be noted that the study aimed to investigate consumer behaviors about functional foods in a healthy population, due to the possibility of an altered opinion in the case of the presence of pathological situations.

\subsubsection{Functional Food Consumption Evaluation}

Functional food consumption was evaluated by a validated questionnaire. This questionnaire was a food frequency questionnaire (FFQ) similar to the one used in NHANES (National Health and Nutritional Examination Survey) study [26], with some modifications. Particularly, changes were carried out with a view to include more natural functional foods, without alterations to the type of questions [11]. Participants were informed on the suggested portion sizes of each of the included foods and were asked based on that about their usual frequency of consumption. The frequency of consumption was recorded as 'everyday', '3-6 times per week', '2 times per week', 'once a week', '1-2 times per month' and 'seldom/never'. The questionnaire also included questions regarding demographic characteristics (age, gender, occupation, etc.), anthropometric indicators (weight, heigh), history of clinical condition and a general nutritional history of the participants.

An extension of this questionnaire was completed by a subsample of 550 participants and included questions on the factors affecting their purchasing of functional food choices and namely the price, nutritional value, taste, brand, packaging and health benefits, as well as their knowledge about functional foods.

\subsubsection{Anthropometric Data}

Participants self-reported their weight and heigh. BMI was calculated by dividing weight $(\mathrm{kg})$ by squared height $\left(\mathrm{m}^{2}\right)$. The classification of the participants according to their BMI was conducted following WHO guidelines $[27,28]$. Specifically, participants with a BMI lower than $18.5 \mathrm{~kg} / \mathrm{m}^{2}$ were classified as underweight, overweight with a BMI greater than or equal to $25 \mathrm{~kg} / \mathrm{m}^{2}$ and obese when their BMI was greater than or equal to $30 \mathrm{~kg} / \mathrm{m}^{2}$.

\subsubsection{Statistical Analysis}

Statistical analysis was performed using the SPSS package, version 16.1 (SPSS Inc, Chicago, IL, USA). We deemed statistical significance at $p=0.05$. The total antioxidant and phenolic content of the selected food products were expressed as the mean \pm standard deviation (SD). Kruskal-Wallis and Ducan's multiple comparison tests were used to investigate the differences between the food samples. The frequency of functional food consumption, as well as eating habits and preferences of the participants, was presented using descriptive statistics. The Pearson test was conducted for analyzing the correlation between BMI and food frequency consumption and the chi-square test to test differences between genders regarding their knowledge and preferences on functional foods. 


\section{Results}

\subsection{In Vitro Study}

The results of the determination of the total antioxidant activity with the FRAP assay are presented in Figure 1. Antioxidant activity of mountain tea presented significantly statistical differences with all the analyzed samples, namely blueberries $(\mathrm{p}<0.005)$, cranberries $(p<0.001)$, pomegranate $(p<0.001)$, grapefruit $(p<0.001)$, red peppers $(p<0.001)$ and almonds $(p<0.001)$. More specifically, mountain tea had the greatest antioxidant activity $335.19 \pm 5.07 \mathrm{mmol} \mathrm{Fe}{ }^{2+} / \mathrm{g}$ of sample, followed by pomegranate with $106.29 \pm 2.82 \mathrm{mmol}$ $\mathrm{Fe}^{2+} / \mathrm{g}$, blueberries with $74.05 \pm 1.92 \mathrm{mmol} \mathrm{Fe}{ }^{2+} / \mathrm{g}$ and almonds with $67.80 \pm 1.67 \mathrm{mmol}$ $\mathrm{Fe}^{2+} / \mathrm{g}$, respectively, without exhibiting statistically important differences. Red peppers with $36.55 \pm 4.91 \mathrm{mmol} / \mathrm{L}$, cranberries $36.73 \pm 5.85 \mathrm{mmol} \mathrm{Fe}^{2+} / \mathrm{g}$ and grapefruits with $28.07 \pm 2.67 \mathrm{mmol} \mathrm{Fe}^{2+} / \mathrm{g}$, had lower total antioxidant activity, but this was not statistically significant.

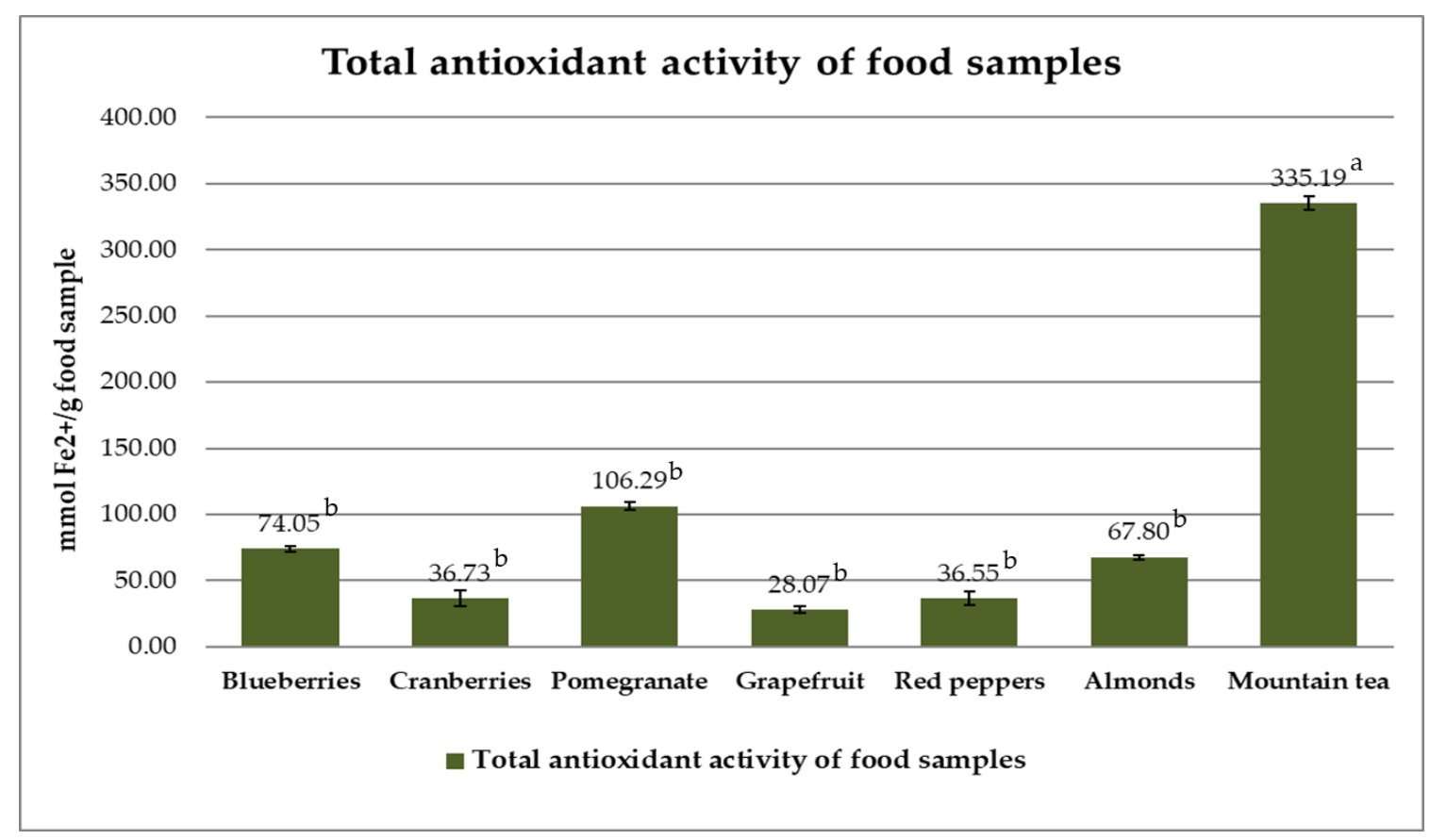

Figure 1. Mean values of total antioxidant activity of different food extracts as determined by Ferric Reducing Antioxidant Power (FRAP) assay. Statistically significant differences are portrayed with superscripts (different letters).

The mean values and the statistically important differences of the total phenolic compounds quantified in the food extracts by Folin-Ciocalteau analysis are presented in Figure 2. The highest content of phenolic compounds was determined in the mountain tea extract with a mean value of $867.95 \pm 6.89 \mathrm{mg}$ gallic acid/g of food sample. Next were almonds with $355.00 \pm 2.17 \mathrm{mg}$ gallic acid $/ \mathrm{g}$, blueberries with $171.25 \pm 0.84 \mathrm{mg}$ gallic acid/g, and pomegranate with $90.51 \pm 1.13 \mathrm{mg}$ gallic acid/g. Grapefruit with $78.52 \pm$ $0.61 \mathrm{mg}$ gallic acid $/ \mathrm{g}$, cranberries with $66.65 \pm 0.86 \mathrm{mg}$ gallic acid/g and red peppers with $49.51 \pm 0.76 \mathrm{mg}$ gallic acid/g were the samples with the lowest concentrations of total phenolic content. Statistically important differences were observed between the mountain tea and all the analyzed food samples $(p<0.001)$, except for almonds $(p>0.05)$. The total phenolic content of almonds also exhibited statistically important differences compared to all analyzed foods, except for mountain tea $(p<0.001)$. In addition, statistically important differences were observed between the total phenolic content of blueberries and red peppers $(p<0.05)$. 


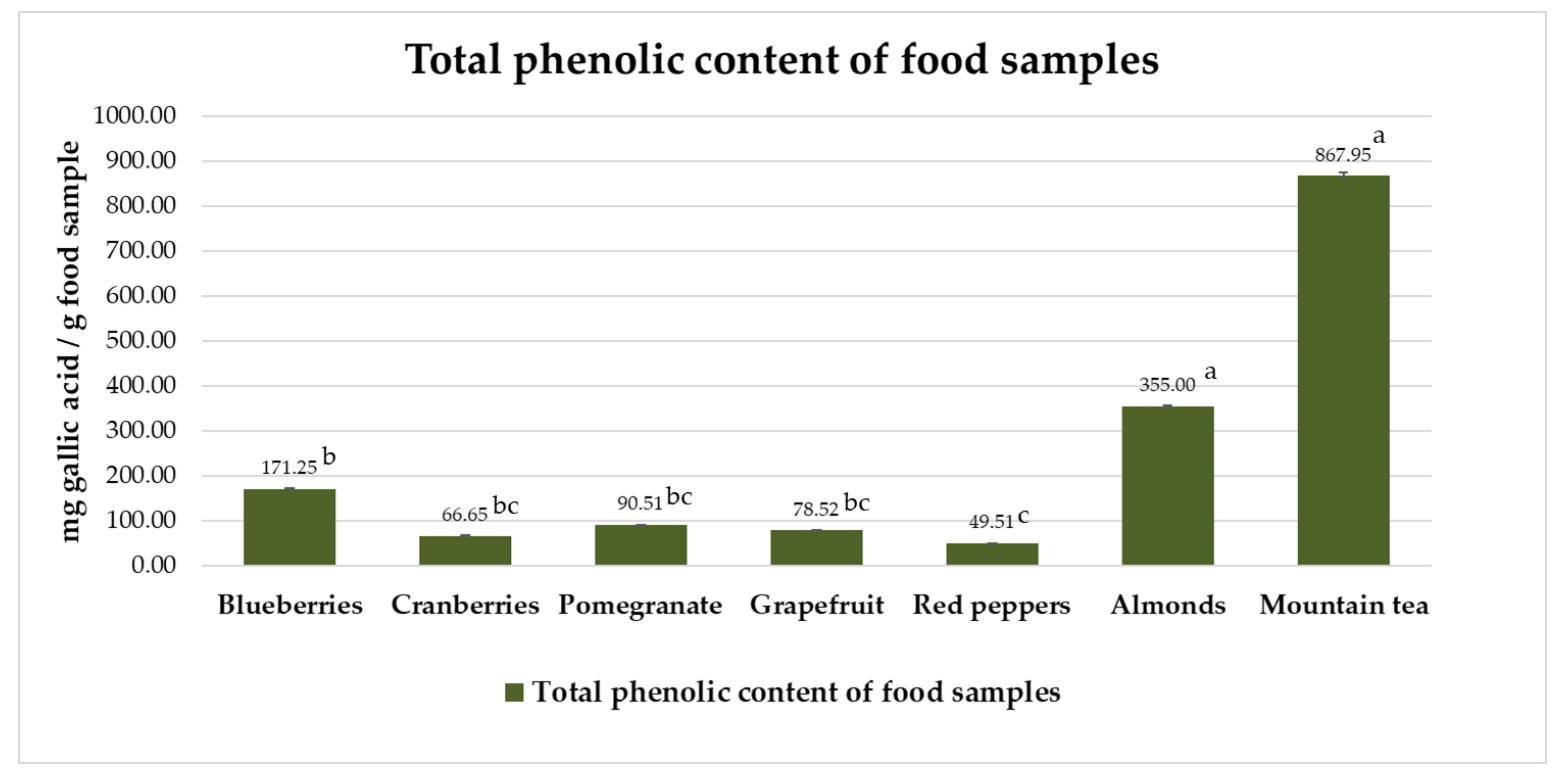

Figure 2. Mean and SD values of total phenolic content of different food samples as determined by the Folin-Ciocalteau assay. Statistically significant differences are portrayed with superscripts (different letters).

As summarized in Table 1, there are several studies in the literature referring to the total antioxidant and phenolic content of the selected foods determined with FRAP and Folin-Cioalteu assay.

Table 1. Mean concentrations of total phenolic content and total antioxidant activity of blueberries, cranberries, pomegranates, grapefruits, red peppers, almonds, and mountain tea reported in literature.

\begin{tabular}{|c|c|c|c|c|}
\hline Food Sample & Origin of Samples & $\begin{array}{l}\text { FRAP Assay } \\
\left(\mathrm{mmol} \mathrm{Fe}^{2+} / \mathrm{g}\right)\end{array}$ & $\begin{array}{l}\text { Folin-Ciocalteu } \\
\text { (mg GA/g) }\end{array}$ & Study \\
\hline \multirow[t]{6}{*}{ Blueberries } & Poland & - & 0.52 & Olas et al. [29] \\
\hline & Turkey & - & $1.58-27.84$ & Gundesli [30] \\
\hline & Turkey & - & $2.65-3.67$ & Zorenc et al. [31] \\
\hline & Italy & $1.98-10.29$ & - & Zorzi et al. [32] \\
\hline & Brazil & $0.25-0.31$ & $19.22-34.56$ & Pertuzatti et al. [33] \\
\hline & Australia & 0.37 & 2.93 & Subbiah et al. [34] \\
\hline \multirow[t]{5}{*}{ Cranberries } & Poland & - & $1.20-3.15$ & Olas et al. [29] \\
\hline & Poland & 1.02 & - & Oszmianski et al. [35] \\
\hline & Hawaii & 0.45 & - & Hummer et al. [36] \\
\hline & USA & - & 1.60 & Kovacev et al. [37] \\
\hline & Poland & - & 2.5 & Skowron et al.[38] \\
\hline \multirow[t]{3}{*}{ Pomegranates } & Spain & 61.28 & 40.74 & Martinez et al. [39] \\
\hline & Croatia & $10.03-17.66$ & $57.66-105.99$ & Peršurić et al. [40] \\
\hline & Iran & - & 22.61 & Basiri et al. [41] \\
\hline \multirow[t]{3}{*}{ Grapefruits } & Cina & $0.93-1.76$ & - & Xi et al. [42] \\
\hline & China & 23.46 & - & Chen et al. [43] \\
\hline & Poland & 0.46 & 0.05 & Muzykiewicz et al. [44] \\
\hline \multirow[t]{4}{*}{ Red peppers } & Brazil & 0.004 & 1.19 & Sora et al. [45] \\
\hline & Iran & 0.5 & - & Shotorbani et al. [46] \\
\hline & Thailand & 0.28 & 3.21 & Thuphairo et al. [47] \\
\hline & Malaysia & 0.003 & 47.06 & Huei1 et al. [48] \\
\hline \multirow[t]{5}{*}{ Almonds } & Italy & $0.041 \mathrm{mmol} \mathrm{Fe}{ }^{2+} / \mathrm{g}$ & - & Pelegrini et al. [49] \\
\hline & California & $36.8-88.8 \mathrm{mmol} \mathrm{Fe}^{2+} / \mathrm{g}$ & $0.58-1.59$ & Bolling et al. [50] \\
\hline & China & - & 8 & Qureshi et al. [51] \\
\hline & Italy & - & 334.20 & Bottone et al. [52] \\
\hline & Italy & & 21.43-141.06 & Bottone et al. [53] \\
\hline \multirow[t]{3}{*}{ Mountain tea } & Greece & $0.03-0.11$ & $2.37-4.56$ & Linardaki et al. [54] \\
\hline & Greece & 0.13 & 18.63 & Goulas et al. [55] \\
\hline & Spain & & 102.54 & de la Puerta et al. [56] \\
\hline
\end{tabular}




\subsection{Epidemiological Study}

According to the demographic characteristics recorded in the epidemiological study, a total of 949 participants (524 women and 425 men) took part in the study, with $51.0 \%$ aged between 18 to 29 years old. The majority of the participants weren't married $(51.3 \%)$ and had reached a higher educational level (53.8\%). The demographic profile of the participants of the study is depicted in Table 2.

Table 2. Profile of the participants of the epidemiologic study.

\begin{tabular}{ccc}
\hline Gender & N & \% \\
\hline Female & 524 & 55.2 \\
Male & 425 & 44.8 \\
\hline Age & & \\
\hline $18-29$ & 484 & 51.0 \\
$30-39$ & 214 & 22.6 \\
$40-49$ & 170 & 17.9 \\
50 and above & 81 & 8.5 \\
\hline Marital Status & & \\
Single/never married & 487 & 51.3 \\
Currently married & 401 & 42.3 \\
Widowed & 36 & 3.8 \\
Divorced/separated & 25 & 2.6 \\
\hline Education & & 8.2 \\
\hline Primary Education & 78 & 30.0 \\
Secondary Education & 285 & 53.8 \\
Higher Education & 511 & 6.3 \\
Master/Doctoral & 60 & 1.6 \\
Other & 15 & 100 \\
\hline Total & 949 &
\end{tabular}

In addition, most of the participants $(67.7 \%)$ were nonsmokers and $35.5 \%$ of them were exercising at least two times per week. In terms of their BMI distribution, $1.7 \%$ were within the underweight range, $35.7 \%$ were evaluated as healthy, $36.2 \%$ as overweight, and $26.3 \%$ as obese.

Consumption frequencies for the above investigated functional foods namely for the consumption of blueberries, cranberries, pomegranates, grapefruits, red peppers, almonds and mountain tea and their association with the BMI of the participants, are presented in Table 3.

Table 3. Frequency of consumption of blueberries, cranberries, pomegranates, grapefruits, red peppers, almonds, and mountain tea by the participants.

\begin{tabular}{ccccccc}
\hline Food Item & $\begin{array}{c}\text { Seldom/Never } \\
\mathbf{( \% )}\end{array}$ & $\begin{array}{c}\text { 1-2 Times Per } \\
\text { Month } \mathbf{( \% )}\end{array}$ & $\begin{array}{c}\text { Once A Week } \\
\mathbf{( \% )}\end{array}$ & $\begin{array}{c}\text { 2 Times Per } \\
\text { Week (\%) }\end{array}$ & $\begin{array}{c}\text { 3-6 Times Per } \\
\text { Week (\%) }\end{array}$ & $\begin{array}{c}\text { Everyday } \\
\mathbf{( \% )}\end{array}$ \\
\hline Blueberries & 0.8 & 3.8 & 7.3 & 20.5 & 60.3 & 7.5 \\
Cranberries & 25.6 & 18.0 & 11.0 & 14.5 & 24.2 & 6.6 \\
Pomegranates & 17.5 & 29.9 & 17.2 & 17.9 & 16.4 & 1.1 \\
Grapefruits & 0.1 & 2.3 & 6.5 & 19.5 & 57.6 & 14.0 \\
Red Peppers & 0.1 & 2.3 & 6.5 & 19.5 & 57.5 & 14.0 \\
Almonds & 4.3 & 9.0 & 18.3 & 43.0 & 23.0 & 2.5 \\
Mountain Tea & 15.9 & 23.1 & 20.5 & 21.0 & 15.1 & 4.4 \\
\hline
\end{tabular}

The Pearson correlation analysis between BMI and the consumption of the different foods, showed a negative correlation in the case of cranberries $(r=0.310, p<0.001)$, 
pomegranate $(\mathrm{r}=0.190, p<0.001)$, grapefruit $(\mathrm{r}=0.179, p<0.001)$, red peppers $(\mathrm{r}=0.134$, $p<0.05)$ and mountain tea $(\mathrm{r}=0.167, p<0.001)$. Specifically, the increased consumption of these functional foods correlated significantly with decreased BMI. No statistically significant correlation was observed for blueberry and almond consumption (Table 4).

Table 4. Association of functional foods consumption with Body Mass Index (BMI) of the participants.

\begin{tabular}{ccc}
\hline Pearson Correlation & & BMI \\
\hline Blueberries & $\mathrm{R}$ & -0.010 \\
& $p$ & 0.839 \\
\hline Cranberries & $\mathrm{R}$ & $-0.310^{*}$ \\
& $p$ & 0.000 \\
\hline Pomegranates & $\mathrm{R}$ & $-0.190^{*}$ \\
& $p$ & 0.000 \\
\hline Grapefruits & $\mathrm{R}$ & $-0.179 *$ \\
& $p$ & 0.000 \\
\hline Red Peppers & $\mathrm{R}$ & $-0.134^{*}$ \\
& $p$ & 0.007 \\
\hline Almonds & $\mathrm{R}$ & -0.007 \\
& $p$ & 0.887 \\
\hline Mountain Tea & $\mathrm{R}$ & $-0.167^{*}$ \\
& $p$ & 0.000 \\
\hline
\end{tabular}

${ }^{*}$ Correlation is significant at $p=0.05$ level.

A subsample of 550 participants completed an extension of the questionnaire by answering a question regarding their functional food purchasing preferences. The participant's knowledge of the term and properties of "functional foods" was also evaluated. Of the participants, $62.9 \%$ correctly reported that functional foods are foods that have beneficial components and $29.8 \%$ had a wrong belief regarding functional foods, such as they are in the form of pills, are organic, genetically modified and $17.3 \%$ were not aware of the term "functional food". In addition, they were asked how price, taste, package, brand and reported health benefits affect their choice when buying functional foods. As seen in Table 5, price, taste, health benefits and nutritional value of functional foods significantly affected the purchasing options of both male and female consumers. Price was the only factor that statistically affected the choices between males and females $(p<0.001)$.

Table 5. \% Percentages of participants replies regarding how (not at all, neutral, much) price, taste, package, brand, reported health benefits and nutritional value affects their functional food purchasing choices.

\begin{tabular}{|c|c|c|c|c|c|c|c|}
\hline & & Price & Taste & Package & Brand & Health Benefits & Nutritional Value \\
\hline \multirow{3}{*}{$\begin{array}{c}\text { Male } \\
(\mathrm{n}=247)\end{array}$} & Not at all & $9.7 \%$ & $8.1 \%$ & $49.0 \%$ & $44.1 \%$ & $6.1 \%$ & $4.9 \%$ \\
\hline & Neutral & $38.5 \%$ & $40.9 \%$ & $39.7 \%$ & $38.9 \%$ & $17.4 \%$ & $19.0 \%$ \\
\hline & much & $51.8 \%$ & $51.0 \%$ & $11.3 \%$ & $17.0 \%$ & $76.5 \%$ & $76.1 \%$ \\
\hline \multirow{3}{*}{$\begin{array}{l}\text { Female } \\
(\mathrm{n}=303)\end{array}$} & Not at all & $8.3 \%$ & $5.3 \%$ & $47.5 \%$ & $39.9 \%$ & $4.3 \%$ & $2.6 \%$ \\
\hline & Neutral & $33.7 \%$ & $28.1 \%$ & $39.9 \%$ & $43.2 \%$ & $16.5 \%$ & $20.8 \%$ \\
\hline & much & $57.8 \%$ & $66.7 \%$ & $12.5 \%$ & $16.8 \%$ & $79.2 \%$ & $76.6 \%$ \\
\hline
\end{tabular}

\section{Discussion}

In the last decade, functional foods have been extensively studied, with the application of in vitro methods, for the determination of their total antioxidant capacity and phenolic content, as well as the quantification of their specific bioactive compounds. In the present study, we evaluated the total antioxidant and phenolic content of blueberries, cranberries, pomegranates, grapefruits, red peppers, almonds, and mountain tea. Among them, moun- 
tain tea and almonds had the highest values for total phenolics; mountain tea additionally exerted the highest values of total antioxidant capacity. Previously published studies on the determination of the antioxidant and total phenolic content of the above-studied foods, however, presented a wide range of values. This may be due to differences in the extraction method during sample preparation, differences in the variety of the analyzed sample [57], as well as differences in the climatic and soil conditions [58] and therefore the origin of the samples. Recent studies suggest, that foods high in antioxidants over the range of 0.87 mmol Fe $\mathrm{Fe}^{2+} / \mathrm{g}$ of dry sample can be used for the fortification of yogurt [59] and can increase the concentration of total antioxidant compounds of the final product [60]. Therefore, we can assume that mountain tea, almonds, blueberries, and pomegranates cultivated in Southern Greece can be used as a potential source of antioxidants, either by consuming them as a whole or in the form of extracts for the enrichment of foods, that present benefits to human health.

Epidemiological, as well as interventional studies, support the association between the consumption of foods rich in antioxidants and phenolic compounds with weight control $[10,61]$. Aiming to investigate this hypothesis, the consumption of the above investigated functional foods was evaluated in terms of their association with the BMI of the consumers. The selected functional foods are usually consumed as part of the Mediterranean diet and they have previously been correlated with a possible role in obesity prevention [10]. Indeed, frequency of consumption showed an association with the BMI of the people that habitually consumed them. More specifically, participants that were frequently consuming cranberries, pomegranates, grapefruits, red peppers, or mountain tea, were observed to have lower BMI values. Several studies indicated that functional foods may have a potential effect on anthropometric indicators and thus, on human health and that antioxidants may contribute towards the management of obesity [62]. In a study by Ntrigios et al. (2019), the frequent consumption of goji berry, cranberry and pomegranate has concluded in a reduced BMI [11]. Antioxidant activity is suggested to ameliorate the inflammation and oxidative stress caused by obesity and is thus considered to potentially benefit inpatients $[63,64]$. Therefore, taking into consideration that obesity, as part of a metabolic syndrome, is a major lifestyle disorder around the world, a healthy diet and functional food consumption can act as a complementary approach, aiming to decrease the incidence of the disease [7]. The synergistic effect of both antioxidant and other bioactive compounds of the specific functional foods may affect procedures, such as fatty acid oxidation, lipolysis, thermogenesis, and satiety, contributing to BMI reduction and weight control. According to our opinion, this study in a healthy population underlines the trends about possible correlations between specific functional food consumption and BMI, contributing to the establishment of nutritional policies about obesity prevention. However, more interventional studies should be performed for safer and clearer results [10]. Nevertheless, other studies with different designs should also be conducted in order to further investigate the association between functional food consumption and weight gain in patients with chronic diseases, such as obesity and metabolic syndromes.

In order to take advantage of the possible health benefits of the above investigated functional foods, it is important for consumers to get familiar with their consumption and include them in their daily diet. The majority of the consumers that participated in the current study, seemed to purchase and consume blueberries, grapefruits and red peppers. Only the minority of the participants consumed blueberries, cranberries, pomegranates, almonds and mountain tea on a daily basis, although their health benefits are evident [10]. It remains interesting, that previous studies conducted in Greece, investigating the frequency of consumption of fruits and vegetables reported that most of the participants consumed them on a daily basis [65]. However, in our study blueberries, cranberries, pomegranates, and almonds were not observed to be in a consumer's weekly choice. In addition, although Greece has a history in herb cultivation [66], preparation and consumption of hot beverages from these herbs are not yet popular among consumers [67]. 
Therefore, it remains important for consumers to be informed about the health benefits of the above-investigated foods and to incorporate them into their diet. However, studies have shown that consumers often cannot understand how specific foods can contribute to the promotion of their health and the role that specific nutrients present [68]. As health is assumed an important factor affecting consumers in their choice of purchasing food products [19], it can be used as a driver to raise awareness on functional foods [15]. In addition, to achieve so, it also remains important to understand better the perceptions and attitudes of consumer purchasing behavior in terms of functional foods in general.

Our study showed that, although consumers were not familiar with the term "functional food", as recently also Tsatsou et al. noted [21], they seemed to be aware of the beneficial components of functional foods, which is in accordance with another study conducted in Greece [14]. When purchasing functional foods, they were greatly evaluating the price, taste, reported health benefits and nutritional value of the products. The information included in the label of foods, such as the reported health claims and nutritional value, were therefore positively affecting consumer purchasing choices [69] and should provide consumers with the adequate information on the beneficial role of food products, always in accordance with EU Commission principles [70] to avoid misleading them [71]. However, it should be noted that consumers are not always familiar with the terms used to describe the nutritional value of products, and therefore it remains important to promote an understanding of the beneficial role of nutrients [68], such as in the case of antioxidant and phenolic compounds [72]. In addition, it is reported that consumers are not aware of the specific nutrient food sources for antioxidants and phenolics [73,74], and this can be evaluated as a barrier affecting their food purchasing behavior. On the o5ther hand, high price seems to negatively affect consumer intentions to buy functional foods [18]. Although consumers seem to be willing to pay higher prices for high nutritional value products [75], the exact price depends on their preferred nutritional properties [19]. However, as assumed in other studies, consumers may seem reluctant to purchase a product by choosing health benefits over taste [76]; therefore, taste remains an important factor for consumer choices. In our study brand familiarity of the products seemed to affect consumers neutrally, potentially because of their stated interest in healthy food choices [77]. Studies have concluded in diverse results regarding brand influence on consumer choices with some reporting high influence and other reporting modest [78]. Country-specific differences seem to play an important role in consumer preferences and attitudes [75,79]. Therefore, it remains important to explore the factors that influence consumer attitudes and intentions towards purchasing functional foods, based on cultural differences.

Finally, some limitations of the present study should be considered. Antioxidant activity and the phenolic content of food samples could also be determined with a more accurate methodology such as High-Performance Liquid Chromatography (HPLC) analysis for the quantification of the consumed polyphenols and other antioxidant components. Moreover, although participants of the study were across Greece, the sample cannot be assumed as representative of the overall population, mainly in terms of socio-economical characteristics and income category. Therefore, the results regarding BMI association with frequency of consumption of the investigated functional foods, as well as the functional food purchasing behavior of the consumers, should be interpreted carefully, as differences may occur comparatively to the general population preferences and characteristics. Thus, larger interventional and clinical studies should be performed in order to determine more accurately the association between the consumption of the above-investigated foods and the BMI of the consumers, as well as the behavioral trends and digestibility of the consumed bioactive compounds. Furthermore, for this study, we selected specific natural functional foods of the Mediterranean diet, based on their possible association with BMI reduction, and therefore we did not include products assumed as main components of this specific diet, such as olive oil. 


\section{Conclusions}

In conclusion, blueberries, cranberries, pomegranates, grapefruits, red peppers, almonds and mountain tea exhibited increased antioxidant activity and phenolic content while their consumption is potentially related to BMI and weight control. Rising health consciousness among consumers regarding the beneficial role of Mediterranean functional foods to human health can act as an important driver for their acceptance and incorporation into their daily diet. However, it remains essential to always take other factors into consideration such as the price and taste of the functional products. The present study could contribute to the initial understanding of functional food consumption in the Greek population in order for nutritional policies to be established with the aim of health promotion. However, more research, clinical and epidemiological studies, should be performed in order to further investigate the mechanisms that specific Mediterranean functional foods may contribute to weight management and disease prevention, as well as consumer behaviors about functional foods.

Author Contributions: Conceptualization, A.E.K. and A.K.; Methodology, M.T., O.K., C.N., G.K. and A.E.K.; Software, A.K.; Validation, A.K.; Formal analysis, A.K., M.T., O.K., C.N. and G.K.; Investigation, A.P., H.C.K., C.N., G.K., M.T. and O.K.; Resources, H.C.K., A.P. and I.-N.E.; Data Curation, A.K. and A.E.K.; Writing-Original Draft Preparation, A.K. and I.-N.E.; Writing-Review and Editing, A.E.K., A.K., I.-N.E., M.T., O.K., C.N., G.K., A.P. and H.C.K.; Visualization, A.E.K. and A.K.; Supervision, A.E.K.; Project Administration, A.E.K. All authors have read and agreed to the published version of the manuscript.

Funding: This work was supported by the ERDF research regional program of the Western Greece entitled "Production of innovative olive-based biscuits with dietary added value" grant number: DEP6-0022676, granted to the Greek food-olive company AMALTHIA S.A.

Institutional Review Board Statement: The study was conducted according to the guidelines of the Declaration of Helsinki. The study not approved by ethics because at the beginning of the study the Ethics Committee of University of the Aegean was not established.

Informed Consent Statement: Informed consent form was obtained from all subjects involved in the study.

Data Availability Statement: The data presented in this study are available within this article.

Acknowledgments: The authors thank all the contributors to the study for their cooperation and contribution.

Conflicts of Interest: The authors declare no conflict of interest.

\section{References}

1. Koutelidakis, A.E. Functional Foods: Their Role on Health Promotion; Ziti: Thessaloniki, Greece, 2015.

2. Papagianni, O.; Loukas, T.; Magkoutis, A.; Biagki, T.; Dimou, C.; Karantonis, C.; Koutelidakis, A. Postprandial bioactivity of spread cheese, enhanced with mountain tea and orange peel extract, in healthy volunteers. A pilot study. Proceedings 2020, 70 , 7671. [CrossRef]

3. Alkhatib, A.; Tsang, C.; Tiss, A.; Bahorun, T.; Arefanian, H.; Barake, R.; Khadir, A.; Tuomilehto, J. Functional foods and lifestyle approaches for diabetes prevention and management. Nutrients 2017, 9, 1310. [CrossRef]

4. Elmaliklis, I.-N.; Liveri, A.; Ntelis, B.; Paraskeva, K.; Goulis, I.; Koutelidakis, A.E. Increased functional foods' consumption and mediterranean diet adherence may have a protective effect in the appearance of gastrointestinal diseases: A case-control study. Medicines 2019, 6, 50. [CrossRef] [PubMed]

5. Elmaliklis, I.-N.; Miserli, E.; Filipatou, M.; Tsikouras, I.; Dimou, C.; Koutelidakis, A. Association of mediterranean diet adherence, functional food consumption and anthropometric characteristics with anxiety and depression indexes in a sample of healthy greek adults: A cross-sectional study. Psychiatry Int. 2020, 1, 14. [CrossRef]

6. Koutelidakis, A.; Dimou, C. The effects of functional food and bioactive compounds on biomarkers of cardiovascular diseases. In Functional Foods Text Book, 1st ed.; Martirosyan, D., Ed.; Functional Food Center: Dallas, TX, USA, 2017; pp. 89-117.

7. Brown, L.B.; Poudyal, H.; Panchal, S.K. Functional foods as potential therapeutic options for metabolic syndrome. Obes. Rev. 2015, 16, 914-941. [CrossRef] [PubMed]

8. Mohamed, S. Functional foods against metabolic syndrome (obesity, diabetes, hypertension and dyslipidemia) and cardiovasular disease. Trends Food Sci. Technol. 2014, 35, 114-128. [CrossRef] 
9. World Health Organization. Obesity and Overweight. Available online: https://www.who.int/news-room/fact-sheets/detail/ obesity-and-overweight (accessed on 2 December 2020).

10. Konstantinidi, M.; Koutelidakis, A.E. Functional foods and bioactive compounds: A review of its possible role on weight management and obesity's metabolic consequences. Medicines 2019, 6, 94. [CrossRef]

11. Ntrigios, I.; Ntrigiou, V.; Dimou, C.; Rigopoulos, N.; Koutelidakis, A. Correlation of specific functional foods consumption with anthropometric characteristics and body composition on a sample of 18-65 years old aged adults from Greece. In Proceedings of the 22nd International Conference Functional Foods and Chronic Diseases: Science and Practice, Boston, MA, USA, 22 September 2017.

12. Petridis, A.; Koukourikou, M.; Sotiropoulos, T.; Stylianidis, D. Antioxidant activity of fruits produced in Northern Greece. HortScience 2010, 45, 1341-1344. [CrossRef]

13. Skrovankova, S.; Sumczynski, D.; Mlcek, J.; Jurikova, T.; Sochor, J. Bioactive compounds and antioxidant activity in different types of berries. Int. J. Mol. Sci. 2015, 16, 24673-24706. [CrossRef]

14. Karelakis, C.; Zevgitis, P.; Galanopoulos, K.; Mattas, K. Consumer trends and attitudes to functional foods. J. Int. Food Agribus. Mark. 2019, 32, 266-294. [CrossRef]

15. Nguyen, N.; Nguyen, H.V.; Nguyen, P.T.; Tran, V.T.; Nguyen, T.M.N.; Cao, T.K.; Nguyen, T.H.; Nguyen, H.N.; Nguyen, H.; Nguyen, H. Some key factors affecting consumers' intentions to purchase functional foods: A case study of functional yogurts in Vietnam. Foods 2019, 9, 24. [CrossRef]

16. Nguyen, T.B.L.; Nguyen, N.; Phan, T.T.H.; Bui, L.P.; Moon, H.C. Investigating consumer attitude and intention towards online food purchasing in an emerging economy: An extended TAM approach. Foods 2019, 8, 576. [CrossRef] [PubMed]

17. Papp-Bata, A.; Csiki, Z.; Szakály, Z. Az egészségvédő élelmiszerekkel kapcsolatos fogyasztói magatartás. A hiteles tájékoztatás szerepe. Orvosi Hetil. 2018, 159, 1221-1225. [CrossRef] [PubMed]

18. Huang, L.; Bai, L.; Zhang, X.; Gong, S. Re-understanding the antecedents of functional foods purchase: Mediating effect of purchase attitude and moderating effect of food neophobia. Food Qual. Prefer. 2018, 73, 266-275. [CrossRef]

19. Pappalardo, G.; Lusk, J.L. The role of beliefs in purchasing process of functional foods. Food Qual. Prefer. 2016, 53, 151-158. [CrossRef]

20. Christidis, N.; Tsoulfa, G.; Varagunam, M.; Babatzimopoulou, M. A cross sectional study of consumer awareness of functional foods in Thessaloniki, Greece. Nutr. Food Sci. 2011, 41, 165-174. [CrossRef]

21. Tsartsou, E.; Proutsos, N.; Papadopoulos, I.; Tzouvelekas, V.; Castanas, E.; Kampa, M. Consumers' attitude toward dietary supplements and functional food: A prospective survey in a Greek population sample. Hormones 2020, 20, 177-188. [CrossRef]

22. Benzie, I.; Strain, J. The ferric reducing ability of plasma (FRAP) as a measure of "antioxidant power": The FRAP assay. Anal. Biochem. 1996, 239, 70-76. [CrossRef]

23. Cao, G.; Prior, R.L. Comparison of different analytical methods for assessing total antioxidant capacity of human serum. Clin. Chem. 1998, 44, 1309-1315. [CrossRef] [PubMed]

24. Kapsokefalou, M.; Zhu, L.; Miller, D.D. Adding iron to green tea may decrease its antioxidant capacity in rats after an oral dose of the mixture. Nutr. Res. 2006, 26, 480-485. [CrossRef]

25. Spanos, G.A.; Wrolstad, R.E. Influence of variety, maturity, processing and storage on the phenolic composition of pear juice. J. Agric. Food Chem. 1990, 38, 817-824. [CrossRef]

26. NHANES. NHANES Food Questionnaire. Available online: https://www.cdc.gov/nchs/data/nhanes/nhanes_03_04/tq_fpq_c. pdf (accessed on 10 December 2019).

27. WHO. Obesity and Overweight Fact Sheet 2021. Available online: https://www.who.int/news-room/fact-sheets/obesity-andoverweight (accessed on 10 June 2021).

28. Birren, J.E. Encyclopedia of Gerontology: Age, Aging, and the Aged; Academic Press: Amsterdam, The Netherlands, 2007; ISBN 978-0-12-370530-3.

29. Olas, B. Berry phenolic antioxidants-Implications for human health? Front. Pharmacol. 2018, 9, 78. [CrossRef] [PubMed]

30. Gundesli, M.; Korkmaz, N.; Okatan, V. Polyphenol content and antioxidant capacity of berries: A review. Int. J. Agric. For. Life Sci. 2019, 3, 350-361.

31. Zorenc, Z.; Veberic, R.; Stampar, F.; Koron, D.; Mikulic-Petkovsek, M. Changes in berry quality of northern highbush blueberry (Vaccinium corymbosum L.) during the harvest season. Turk. J. Agric. For. 2016, 40, 855-864. [CrossRef]

32. Zorzi, M.; Gai, F.; Medana, C.; Aigotti, R.; Morello, S.; Peiretti, P.G. Bioactive compounds and antioxidant capacity of small berries. Foods 2020, 9, 623. [CrossRef]

33. Pertuzatti, P.B.; Barcia, M.T.; Rodrigues, D.; da Cruz, P.N.; Hermosín-Gutiérrez, I.; Smith, R.; Godoy, H.T. Antioxidant activity of hydrophilic and lipophilic extracts of Brazilian blueberries. Food Chem. 2014, 164, 81-88. [CrossRef]

34. Subbiah, V.; Zhong, B.; Nawaz, M.A.; Barrow, C.J.; Dunshea, F.R.; Suleria, H.A.R. Screening of phenolic compounds in Australian grown berries by LC-ESI-QTOF-MS/MS and determination of their antioxidant potential. Antioxidants 2020, 10, 26. [CrossRef] [PubMed]

35. Oszmiański, J.; Kolniak-Ostek, J.; Lachowicz, S.; Gorzelany, J.; Matłok, N. Phytochemical compounds and antioxidant activity in different cultivars of cranberry (Vaccinium macrocarpon L.). J. Food Sci. 2017, 82, 2569-2575. [CrossRef]

36. Hummer, K.; Durst, R.; Zee, F.; Atnip, A.; Giusti, M.M. Phytochemicals in fruits of Hawaiian wild cranberry relatives. J. Sci. Food Agric. 2013, 94, 1530-1536. [CrossRef] 
37. Kovacev, K.; Hughes, B.; Smith, J.S. Polyphenol stability and physical characteristics of sweetened dried cranberries. Foods 2020, 9, 551. [CrossRef] [PubMed]

38. Jeszka-Skowron, M.; Zgoła-Grześkowiak, A.; Stanisz, E.; Waśkiewicz, A. Potential health benefits and quality of dried fruits: Goji fruits, cranberries and raisins. Food Chem. 2017, 221, 228-236. [CrossRef] [PubMed]

39. Martínez, G.N.; Castillo, J.; Ros, G.; Nieto, G. Antioxidant and antimicrobial activity of rosemary, pomegranate and olive extracts in fish patties. Antioxidants 2019, 8, 86. [CrossRef]

40. Peršurić, Z.; Martinović, L.S.; Malenica, M.; Gobin, I.; Pedisić, S.; Dragović-Uzelac, V.; Pavelić, S.K. Assessment of the biological activity and phenolic composition of ethanol extracts of pomegranate (Punica granatum L.) peels. Molecules 2020, $25,5916$. [CrossRef] [PubMed]

41. Basiri, S. Evaluation of antioxidant and antiradical properties of pomegranate (Punica granatum L.) seed and defatted seed extracts. J. Food Sci. Technol. 2013, 52, 1117-1123. [CrossRef]

42. Xi, W.; Fang, B.; Zhao, Q.; Jiao, B.; Zhou, Z. Flavonoid composition and antioxidant activities of Chinese local pummelo (Citrus grandis Osbeck.) varieties. Food Chem. 2014, 161, 230-238. [CrossRef]

43. Chen, Q.; Wang, D.; Tan, C.; Hu, Y.; Sundararajan, B.; Zhou, Z. Profiling of flavonoid and antioxidant activity of fruit tissues from 27 Chinese local citrus cultivars. Plants 2020, 9, 196. [CrossRef] [PubMed]

44. Muzykiewicz, A.; Zielonka-Brzezicka, J.; Klimowicz, A. The antioxidant potential of flesh, albedo and flavedo extracts from different varieties of grapefruits. Acta Sci. Pol. Technol. Aliment. 2015, 18, 453-462. [CrossRef]

45. Sora, G.T.S.; Haminiuk, C.; Da Silva, M.V.; Zielinski, A.; Gonçalves, G.A.; Bracht, A.; Peralta, R.M. A comparative study of the capsaicinoid and phenolic contents and in vitro antioxidant activities of the peppers of the genus Capsicum: An application of chemometrics. J. Food Sci. Technol. 2015, 52, 8086-8094. [CrossRef]

46. Shotorbani, N.Y.; Jamei, R.; Heidari, R. Antioxidant activities of two sweet pepper Capsicum annuum L. varieties phenolic extracts and the effects of thermal treatment. Avicenna J. Phytomedicine 2013, 3, 25-34.

47. Thuphairo, K.; Sornchan, P.; Suttisansanee, U. Bioactive compounds, antioxidant activity and inhibition of key enzymes relevant to Alzheimer's disease from sweet pepper (Capsicum annuum) extracts. Prev. Nutr. Food Sci. 2019, 24, 327-337. [CrossRef]

48. Huei, C.S.; Azlan, A.; Ismail, A.; Shafie, N.H.; Sultana, S. Antioxidant and anti-obesity properties of local chilies varieties in Malaysia. J. Food Sci. Technol. 2020, 57, 3677-3687. [CrossRef]

49. Pellegrini, N.; Serafini, M.; Salvatore, S.; Del Rio, D.; Bianchi, M.; Brighenti, F. Total antioxidant capacity of spices, dried fruits, nuts, pulses, cereals and sweets consumed in Italy assessed by three different in vitro assays. Mol. Nutr. Food Res. 2006, 50, 1030-1038. [CrossRef]

50. Bolling, B.; Dolnikowski, G.; Blumberg, J.B.; Chen, C.-Y.O. Polyphenol content and antioxidant activity of California almonds depend on cultivar and harvest year. Food Chem. 2010, 122, 819-825. [CrossRef]

51. Qureshi, M.N.; Numonov, S.; Aisa, H.A. Total polyphenolic compounds, total flavonoids, GC-MS analysis of volatile constituents, evaluation of antioxidant and antimicrobial activities of Prunus dulcis nuts. Pak. J. Pharm. Sci. 2019, 32, 1461-1466.

52. Bottone, A.; Montoro, P.; Masullo, M.; Pizza, C.; Piacente, S. Metabolite profiling and antioxidant activity of the polar fraction of Italian almonds (Toritto and Avola): Analysis of seeds, skins, and blanching water. J. Pharm. Biomed. Anal. 2020, 190, 113518. [CrossRef] [PubMed]

53. Bottone, A.; Masullo, M.; Montoro, P.; Pizza, C.; Piacente, S. HR-LC-ESI-Orbitrap-MS based metabolite profiling of Prunus dulcis Mill. (Italian cultivars Toritto and Avola) husks and evaluation of antioxidant activity. Phytochem. Anal. 2019, 30, 415-423. [CrossRef]

54. Linardaki, Z.I.; Vasilopoulou, C.G.; Constantinou, C.; Iatrou, G.; Lamari, F.; Margarity, M. differential antioxidant effects of consuming tea from Sideritis clandestina subsp. peloponnesiaca on cerebral regions of adult mice. J. Med. Food 2011, 14, 1060-1064 [CrossRef]

55. Goulas, V.; Exarchou, V.; Kanetis, L.; Gerothanassis, I.P. Evaluation of the phytochemical content, antioxidant activity and antimicrobial properties of mountain tea (Sideritis syriaca) decoction. J. Funct. Foods 2014, 6, 248-258. [CrossRef]

56. De La Puerta, R.; Fernández-Arche, M.; Lopez-Lazaro, M.; Garcia, M. Antioxidant and cytotoxic activities of Sideritis perezlarae (Borja) Roselló, Stübing and Peris. Nat. Prod. Res. 2012, 27, 1602-1606. [CrossRef] [PubMed]

57. Pljevljakušić, D.; Šavikin, K.; Janković, T.; Zdunić, G.; Ristić, M.; Godjevac, D.; Konić-Ristić, A. Chemical properties of the cultivated Sideritis raeseri Boiss. \& Heldr. subsp. Raeseri. Food Chem. 2011, 124, 226-233. [CrossRef]

58. Skenderidis, P.; Kerasioti, E.; Karkanta, E.; Stagos, D.; Kouretas, D.; Petrotos, K.; Hadjichristodoulou, C.; Tsakalof, A. Assessment of the antioxidant and antimutagenic activity of extracts from goji berry of Greek cultivation. Toxicol. Rep. 2018, 5, $251-257$. [CrossRef]

59. Ulewicz-Magulska, B.; Wesolowski, M. Total Phenolic Contents and Antioxidant Potential of Herbs Used for Medical and Culinary Purposes. Plant Foods Hum. Nutr. 2018, 74, 61-67. [CrossRef]

60. Shori, A.B. Inclusion of phenolic compounds from different medicinal plants to increase $\alpha$-amylase inhibition activity and antioxidants in yogurt. J. Taibah Univ. Sci. 2020, 14, 1000-1008. [CrossRef]

61. Karasawa, M.M.G.; Mohan, C. Fruits as prospective reserves of bioactive compounds: A review. Nat. Prod. Bioprospecting 2018, 8, 335-346. [CrossRef]

62. Chen, I.-J.; Liu, C.-Y.; Chiu, J.-P.; Hsu, C.-H. Therapeutic effect of high-dose green tea extract on weight reduction: A randomized, double-blind, placebo-controlled clinical trial. Clin. Nutr. 2016, 35, 592-599. [CrossRef] 
63. Abdali, D.; Samson, S.E.; Grover, A.K. how effective are antioxidant supplements in obesity and diabetes? Med Princ. Pr. 2015, 24, 201-215. [CrossRef]

64. Park, S. Can antioxidants be effective therapeutics for type 2 diabetes? Yeungnam Univ. J. Med. 2021, 38, 83-94. [CrossRef]

65. Lambrinakou, S.; Katsa, M.E.; Zyga, S.; Ioannidis, A.; Sachlas, A.; Panoutsopoulos, G.; Pistikou, A.M.; Magana, M.; Dimoligianni, D.E.K.; Kolovos, P.; et al. Correlations between nutrition habits, anxiety and metabolic parameters in greek healthy adults. Single Mol. Single Cell Seq. 2017, 987, 23-34. [CrossRef]

66. Hatziagapiou, K.; Kakouri, E.; Lambrou, G.; Bethanis, K.; Tarantilis, P. Antioxidant properties of Crocus sativus L. and its constituents and relevance to neurodegenerative diseases; Focus on Alzheimer's and Parkinson's disease. Curr. Neuropharmacol. 2019, 17, 377-402. [CrossRef]

67. Athanasatou, A.; Malisova, O.; Kandyliari, A.; Kapsokefalou, M. Water intake in a sample of Greek adults evaluated with the water balance questionnaire (WBQ) and a seven-day diary. Nutrients 2016, 8, 559. [CrossRef] [PubMed]

68. Annunziata, A.; Mariani, A. Do consumers care about nutrition and health claims? Some evidence from Italy. Nutrients 2019, 11, 2735. [CrossRef]

69. Aschemann-Witzel, J.; Maroscheck, N.; Hamm, U. Are organic consumers preferring or avoiding foods with nutrition and health claims? Food Qual. Prefer. 2013, 30, 68-76. [CrossRef]

70. European Union (EU). Regulation (EU) 1169/2011 of the European parliament and of the Council of 25 October 2011 on the provision of food information to consumers, amending Regulations (EC) No 1924/2006 and(EC) No 1925/2006 of the European Parliament and of the Council, and repealing Commission Directive 87/250/EEC, Council Directive 90/496/EEC, Commission Directive 1999/10/EC, Directive 2000/13/EC of the European Parliament and of the Council, Commission Directives 2002/67/EC and 2008/5/EC and Commission Regulation (EC) No 608/2004 (Text with EEA relevance). Off. J. Eur. Union 2011, $304,18-63$. Available online: https:/ / eur-lex.europa.eu/legal-content/EN/ALL/?uri=CELEX\%3A32011R1169 (accessed on 13 June 2018).

71. Hung, Y.; Hieke, S.; Grunert, K.G.; Verbeke, W. Setting policy priorities for front-of-pack health claims and symbols in the European Union: Expert consensus built by using a delphi method. Nutrients 2019, 11, 403. [CrossRef] [PubMed]

72. Fatkullin, R.; Naumenko, N.; Popova, N.; Ruskina, A.; Kalinina, I.; Potoroko, I. Explaining consumer intentions for foods with antioxidant properties: Predictors of choice and purchase barriers. Int. J. Food Sci. 2021, 2021. [CrossRef]

73. Szúcs, V.; Szabó, E.; Banati, D. Consumer's knowledge of antioxidant components: Results of a questionnaire survey in Hungary. In proceeding of 3nd International Life Sciences Institute Europe, Brussels, Belgium, 31 January 2017.

74. Toner, C. Consumer perspectives about antioxidants. J. Nutr. 2004, 134, 3192S-3193S. [CrossRef] [PubMed]

75. Bimbo, F.; Bonanno, A.; Nocella, G.; Viscecchia, R.; Nardone, G.; De Devitiis, B.; Carlucci, D. Consumers' acceptance and preferences for nutrition-modified and functional dairy products: A systematic review. Appetite 2017, 113, 141-154. [CrossRef]

76. Siegrist, M.; Shi, J.; Giusto, A.; Hartmann, C. Worlds apart. Consumer acceptance of functional foods and beverages in Germany and China. Appetite 2015, 92, 87-93. [CrossRef]

77. Annunziata, A.; Vecchio, R. Consumer perception of functional foods: A conjoint analysis with probiotics. Food Qual. Prefer. 2013, 28, 348-355. [CrossRef]

78. Ares, G.; Giménez, A.; Deliza, R. Influence of three non-sensory factors on consumer choice of functional yogurts over regular ones. Food Qual. Prefer. 2010, 21, 361-367. [CrossRef]

79. Messina, F.; Saba, A.; Turrini, A.; Raats, M.; Lumbers, M.; Team, F.I.L.L. Older people's perceptions towards conventional and functional yoghurts through the repertory grid method. Br. Food J. 2008, 110, 790-804. [CrossRef] 